\section{PERTIMBANGAN PEMILIHAN STRATEGI \\ PEMBELAJARAN SEJARAH DENGAN ORIENTASI STUDENT ACTIVE LEARNING DI SMA}

Moch. Dimas Galuh Mahardika

dimas.dg20@gmail.com

Universitas Sebelas Maret, Indonesia.

Abstract: Today's, learning paradigm has begun to be directed at
student activities become learning centres. History learning, which is
identical to the teacher's domination with the lecture method, has

\section{RJPSI}

ARTICLE INFO:

Research Article

Article history:

Received o7 April 2020

Revised 30 January 2021

Accepted o5 February 2021

Published 16 June 2021

Available online 16 June 2021

(C)2021. Moch. Dimas Galuh Mahardika. All rights reserved. begun to be transformed into empowering independently learning students activities, the goal is oriented towards student active learning. To implement this idea, it's necessary to develop a history learning strategy expected to be achieved that goal. In developing learning strategies that are oriented towards student activities, some basic considerations that are elements in history learning must be considered to provide great opportunities for students to build their knowledge independently. This article is based on the study of literature, then produce an idea as a contribution to improving the quality of history learning.

Keywords: History learning, empowering, student active learning.

\title{
PENDAHULUAN
}

Paradigma baru pembelajaran sejarah di era sekarang telah mengalami tranfsormasi yang sebelumnya pembelajaran didominasi oleh peran guru, sekarang mulai memprioritaskan aktifitas belajar peserta didik secara mandiri. Kehadiran peserta di dalam kelas merupakan suatu konstruk sosio-kultural (Barton \& Levstik, 2004) ketika mereka melakukan interaksi dengan lingkungan belajarnya, baik dengan guru, dengan teman sebaya, maupun dengan sumber belajarnya. Kekuasaan tradisional guru yang kerap mendominasi pembelajaran tampaknya sudah tidak relevan dengan paradigma pembelajaran hari ini. Otoritas guru yang terlalu berlebihan membuat peserta didik tidak terdorong untuk berfikir lebih kritis. Hal semacam ini kerap diistilahkan sebagai pendidikan "gaya bank", peserta didik dianggap sebagai sebuah tempat penyimpanan pengetahuan. Pengetahuan itu 
akan 'dipanggil' apabila dibutuhkan saja (Ahmad, 2016). Tentu metode pengajaran yang demikian tidak lagi menjadi prioritas di dalam pembelajaran abad 21 ini. Kepentingan pembelajaran sejarah tidak hanya semata-mata menceritakan masa lalu kepada siswa melalui ceramah, lebih jauh peserta didik diajak untuk berpikir secara konstruktif dengan pertanyaan mendasar "bagaimana narasi dari persitiwa masa lalu tersebut disusun?" (Lévesque, 2008). Untuk memiliki kesadaran itu diperlukan rangsangan khusus agar siswa mampu memahami untuk apa sebenarnya mereka belajar sejarah. Dalam mengimplementasikan ide tersebut diperlukan kesadaran dan kerendahan hati seorang guru untuk bersedia memberikan kesempatan yang luas kepada siswa di dalam membangun pengetahuan mereka secara mandiri agar siswa juga memiliki hubungan emosional dan intelektual terhadap apa yang mereka pelajari (Hariyono, 2018) sehingga pelajaran sejarah menjadi lebih relevan dengan kehidupan peserta didik.

Persoalan lainnya yang turut mewarnai pengajaran sejarah dari waktu ke waktu salah satunya adalah bobot materi yang begitu berat yang harus diselesaikan peserta didik di sekolah dalam waktu 3 tahun. Apabila dikomparasi dengan kegiatan belajar mahasiswa jurusan sejarah yang selama empat tahun di setiap harinya mereka belajar sejarah, dengan peserta didik sekolah menengah atas yang hanya 2 jam pelajaran dalam satu minggu selama tiga tahun untuk belajar sejarah, dengan kajian materi yang kurang lebih sama (hanya berbeda kedalaman pengkajian). Mahasiswa jurusan sejarah yang belajar sejarah setiap harinya selama 4 tahun terkadang masih tersengal-sengal di dalam memahami sejarah secara utuh, apalagi peserta didik yang belajar sejarah hanya 2 jam pelajaran dalam satu minggu selama 3 tahun saja. Bobot materi yang diasajikan dalam pembelajaran sejarah di sekolah secara kuantitas cukup banyak, namun alokasi waktu yang diberikan cukup minim. Hal semacam ini yang kemudian membuat guru harus kejar mengejar dengan waktu dengan materi yang disampaikan sehingga pembelajaran sejarah kerapkali dianggap membosankan dan terkesan kurang memberikan makna kepada peserta didik (Husbands dkk., 2003). Tentu tidak dapat diperbandingkan capaian tujuan pembelajaran sejarah di sekiolah dengan perkuliahan di kampus. Peserta didik di SMA belajar sejarah dengan menggunakan pendekatan kritis, yakni mulai belajar mengenal konsep kausalitas di dalam peristiwa sejarah. Sedangkan untuk mahasiswa, pengajaran sejarah diberikan dengan menggunakan pendekatan akademis (Kuntowijoyo, 2005).

Pembelajaran sejarah sering dianggap sebagai pembelajaran yang secara substansial memberikan fondasi atau penanaman identitas kepada peserta didik (Epstein, 2009; Metzger \& Harris, 2018), dengan harapan ke depan mereka dapat menjadi insan yang berkarakter. Idealnya, penilaian atas capaian pembelajaran sejarah dilakukan dalam berbagai aspek, baik kognitif, afektif, dan psikomotor. Belum lagi apabila kita melihat dari tujuan pembelajaran sejarah yang termaktub di dalam silabus matapelajaran sejarah kurikulum 2013 (Kementerian Pendidikan dan Kebudayaan, 2017), secara jelas mengatakan bahwa tujuan pembelajaran sejarah adalah untuk memberikan keterampilan berpikir sejarah sekaligus untuk membekali peserta didik dalam membentuk dan menumbuhkan nilai-nilai kebangsaan. Tujuan itu akan dapat dicapai apabila peserta didik memiliki keterampilan berpikir yang kritis dengan daya imajinasi yang mumpuni. Namun di dalam praktiknya, seringkali tujuan itu seolah-olah terlupakan. Banyak problem yang menyebabkan hal tersebut terjadi, 
mulai dari kurangnya profesionalitas guru, minimnya alokasi waktu pembelajaran, kurangnya fasilitas pembelajaran dan beberapa persoalan teknis lainnya. Berkaitan dengan tujuan pembelajaran yang dipaparkan di dalam silabus matapelajaran sejarah kurikulum 2013, dapat diasumsikan bahwa pembelajaran sejarah di dalam kurikulum 2013 mulai mengarah pada asas student active learning, mengingat landasan filosofis dari kurikulum 2013 ini adalah konstruktivisme yang menghendaki peserta didik belajar secara mandiri dalam melakukan konstruk pengetahuan.

Student active learning merupakan jargon yang sering kita dengar hari ini, sebuah istilah yang menengarai transformasi pembelajaran berupa upaya empowering yang mengubah kekuasaan tradisional guru (power over) beserta dominasinya di dalam pembelajaran, menjadi pemberdayaan peserta didik secara maksimal (power with) di dalam membangun pengetahuan dalam kebutuhan belajar mereka (Kreisberg, 1992). Pemberdayaan peserta didik merupakan alternatif yang dianggap sesuai untuk membentuk seumber daya manusia dengan kecakapan abad 21, yakni memberikan mereka kesempatan seluas mungkin untuk aktif bertindak dan berpikir secara kritis dalam menelaah sebuah kajian tanpa harus mendapatkan dominasi atau kungkungan dari otoritas guru (Giroux, 2011). Kebebasan di dalam belajar ini bukan juga semata-mata menghapuskan tugas guru di dalam pembelajaran, porsi dari apa yang disebut sebagai tindakan "partisipatif" di dalam pembelajaran adalah ketika guru dan peserta didik berada pada posisi yang sama di dalam berbagi informasi, tidak saling mendominasi, dan berpegang pada prinsip-prinsip etik demokrasi (Villacañas de Castro, 2016). Apabila dikaitkan dengan landasan konstruktivisme di dalam kurikulum 2013, maka konsep "partisipatif" di dalam kegiatan pembelajaran ini akan menjadi sesuatu yang relevan. Secara konkrit, titik pusat dari aspek partisipatif ini adalah aktifitas peserta didik di dalam kegiatan pembelajaran secara mandiri.

Pengajaran dengan menggunakan pendekatan student active learning ini diharapkan mampu menjadi jalan tengah dari persoalan-persoalan pembelajaran sejarah yang telah dijelaskan sebelumnya. Inti dari pendekatan student active learning adalah untuk memberikan pengalaman secara langsung kepada peserta didik di dalam mengkaji masa lalu sesuai dengan kaidah akademis. Sekaligus juga untuk menjawab pertanyaan "apa sebetulnya tujuan sejarah di ajarkan di sekolah?”. Dengan terlibatnya peserta didik secara langsung, mereka akan memiliki pengalaman intelektual untuk menjawab pertanyaan-pertanyaan historis, yang kira-kira muaranya adalah untuk membentuk sebuah kesadaran sejarah (Seixas, 2004). Tentu saja, di dalam melaksanakan pembelajaran yang berporos pada student active learnig diperlukan berbagai pertimbangan yang mendasar dengan rumusan tujuan yang jelas supaya tujuan pembelajaran sejarah dapat tercapai secara maksimal. Maka dari itu, artikel ini mencoba mengelaborasi apa saja yang menjadi pertimbangan di dalam pemilihan strategi pembelajaran berbasis student active learning untuk pembelajaran sejarah di SMA.

\section{METODE}

Artikel ini merupakan gagasan konseptual penulis yang disusun dengan menggunakan metode studi kepustakaan. Studi kepustakaan merupakan metode penelitian yang didasarkan pada sumber tektual, sumber tekstual yang dimaksudkan dalam konteks penulisan artikel ini adalah buku dan 
jurnal ilmiah. Zed (2004) menyebutkan beberapa karakteristik studi kepustakaan, pertama berhadapan langsung dengan teks. Penulis membaca dan menelaah setiap sumber yang digunakan untuk menemukan sudut pandang tertentu yang kemudian dapat dijadikan dasar untuk membangun narasi dan ide. Kedua, sumber bersifat siap pakai. Sumber tekstual yang digunakan adalah buku dan jurnal, yang notabene akses untuk mendapatkannya sangatlah mudah. Ketiga, sumber yang digunakan umumnya merupakan sumber sekunder. Buku dan jurnal yang digunakan sebagai referensi kebanyakan merupakan hasil dari penelitian para akademisi dan pedagog sejarah. Sumber yang terkumpul kemudian dianalisis dan dikomparasikan, sehingga penulis memiliki dasar argumentasi yang dapat dipertanggungjawabkan secara akademis.

\section{HASIL DAN PEMBAHASAN}

\section{Dasar-Dasar Pertimbangan Pemilihan Strategi Pembelajaran Berbasis Student Active Learning}

Dalam merumuskan perencanaan pembelajaran sejarah, guru perlu untuk memahami beberapa aspek terkait yang menjadi unsur-unsur pembelajaran. Perencanaan pembelajaran yang secara umum berisi tentang strategi pembelajaran disusun sesuai dengan kebutuhan pembelajaran berdasarkan karakteristik kelas, perkembangan teknologi, serta relevansi materi ajar dengan lingkungan peserta didik. Beberapa aspek yang telah disebutkan tidak dapat berdiri dan bekerja sendiri, kesemuanya merupakan suatu kesatuan yang saling bekerja dan memberikan dampak secara langsung dalam praktik pembelajaran sejarah. Pada bagian ini akan dipaparkan penjelasan beberapa unsur yang telah disebutkan.

\section{Karakteristik Kelas}

Pendekatan student active learning memposisikan peserta didik sebagai subjek pembelajaran. Aktifitas pembelajaran secara khusus diprioritaskan untuk pemberdayaan peserta didik di dalam kegiatan belajar. Sebagai upaya menyusun sebuah strategi pembelajaran yang tepat sasaran, maka yang perlu dilakukan terlebih dahulu adalah melakukan pengamatan terhadap karakteristik kelas. Kelas yang notabene dihuni oleh berbagai macam karakter peserta didik dengan berbagai macam kemampuan kognitif yang mereka miliki tentunya harus mendapatkan perlakuan sesuai dengan kebutuhan belajarnya. Peserta didik untuk jenjang SMA adalah golongan remaja yang secara psikologi perkembangan sudah mulai memiliki kesadaran akan tanggungjawab (Gunarsa, 2008; Priansa, 2019).

Melakukan identifikasi awal terhadap perilaku peserta didik dilakukan sebagai dasar pertimbangan guru dalam merancang kegiatan pembelajaran, salah satunya untuk mengidentifikasi secara tepat apa yang sudah diketahui maupun yang belum diketahui peserta didik sebelum mereka melakukan kegiatan instruksional (Dick dkk., 2015). Guru memiliki banyak instrumen untuk mengamati kondisi kelas. Karakteristik kelas misalnya dapat diamati dengan memanfaatkan data peserta didik berupa hasil belajar, untuk memahami kemampuan kognitifnya. Kemudian yang tidak kalah penting adalah pengamatan di lapangan/kelas. Dalam melakukan pengamatan di kelas, aspek yang diamati adalah perilaku peserta didik. 
Aspek kognitif diamati dengan tujuan untuk mengetahui kecerdasan peserta didik dalam aspek akademis. Sedangkan aspek perilaku diamati untuk mengetahui kecerdasan sosial peserta didik di dalam interaksi dengan lingkungan belajarnya. Kecerdasan akademis peserta didik dalam hal ini bukan menjadi fokus pertimbangan, karena dalam konteks student active learning kecerdasan akademis dapat dikembangkan sesuai dengan situasi belajar yang dianggap supportif untuk mengembangkan kecerdasan tersebut (Dewey, 2004). Peserta didik yang tidak memiliki keterampilan kognitif mumpuni bukan berarti ia tidak cerdas. Hasil belajar kognitif yang kurang maksimal ditentukan oleh banyak faktor, salah satunya adalah lingkungan belajar. Maka dari itulah pembelajaran berbasis student active learning diberikan untuk membentuk lingkungan belajar yang dapat membantu peserta didik mencapai hasil belajar kognitif yang maksimal. Aspek yang diamati berikutnya adalah sikap dan perilaku peserta didik di dalam kelas. Perilaku peserta didik oleh Priansa (2019:) diklasifikasikan menjadi empat pola, lihat tabel berikut.

Tabel 1. Empat Pola Tingkah Laku

\begin{tabular}{ll}
\hline \multicolumn{1}{c}{ Pola Tingkah Laku } & \multicolumn{1}{c}{ Penjelasan } \\
\hline Aktif-Konstruktif & $\begin{array}{l}\text { Pola tingkah laku ini bersifat penuh ambisi } \\
\text { dan ingin menjadi pusat perhatian di } \\
\text { kelasnya. Peserta didik dengan karakter } \\
\text { seperti ini memiliki daya dan usaha untuk } \\
\text { membantu guru dengan penuh semangat }\end{array}$ \\
\hline Aktif-Destruktif & Pola tingkah laku ini diwujudkan dalam \\
& bentuk yang kurang positif seperti sikap \\
& marah, kasar, dan cenderung memberontak. \\
& Pola ini akan memberikan ketidaknyamanan \\
& bagi guru dan peserta didik yang lain \\
\hline Pasif-Konstruktif & Pola tingkah laku yang menunjuk pada suatu \\
& bentuk tingkah laku yang lamban dengan \\
& maksud selalu dibantu dan mengharapkan \\
& perhatian dari guru \\
\hline Pasif-Destruktif & Pola tingkah laku yang menunjuk kemalasan \\
& dan keras kepala sehingga merugikan diri \\
& sendiri dan peserta didik lain \\
\hline
\end{tabular}

Sumber: Priansa, 2019: 33.

Ada banyak cara yang dapat digunakan untuk melakukan identifikasi peserta didik dalam kesatuan kelas. Rusman (2012) menawarkan beberapa tahapan yang dianggap efektif untuk melakukan pekerjaan tersebut, di antaranya: (a) observasi; (b) tanya jawab; (c) tabulasi karakteristik pribadi siswa. Observasi menjadi metode yang lazim dan sangat umum digunakan untuk mengamati sebuah fenomena. Dalam kegiatan observasi guru melakukan pengumpulan 
data, analisis, pencatatan, serta pelaporan dengan tujuan mendapatkan data objektif yang relevan dengan kondisi kelas. Metode yang dapat digunakan selanjutnya adalah metode tanya jawab. Tanya jawab merupakan cara penyajian bahan pelajaran melalui bentuk pertanyaan yang harus dijawab oleh peserta didik. Penggunaan metode tanya jawab bertujuan untuk memacu motivasi peserta didik untuk aktif mengemukakan pendapat dalam bentuk pertanyaan maupun argumentasi dalam kegiatan pembelajaran. Metode terakhir adalah tabulasi karakteristik pribadi peserta didik. Metode ini merupakan tahapan terakhir dalam kegiatan identifikasi peserta didik, yakni berbagai hasil dari metode-metode sebelumnya diidentifikasi dan dianalisis untuk melakukan klasifikasi peserta didik yang dianggap bermasalah untuk mendapatkan bimbingan guru yang lebih ekstra, dengan peserta didik yang dianggap tidak memerlukan bimbingan khusus. Artinya, dalam menyikapi perilaku peserta didik, guru perlu untuk memahami kondisi pribadi peserta didik supaya terjalin hubungan yang mutual sesuai dengan kebutuhan peserta didik.

Data yang diperoleh dari berbagai rangkaian identifikasi peserta didik di atas, kemudian dijadikan dasar untuk menyusun strategi pembelajaran. Kelas yang dihuni oleh peserta didik dengan kemampuan kognitif dan perilaku yang homogen, tentu akan berbeda dengan kelas yang sifatnya heterogen. Perlakuan guru dalam mengajar di kedua karakter kelas tersebut tentu saja berbeda. Misalnya di dalam menentukan model pembelajaran, kelas yang berisi peserta didik dengan kemampuan kognitif tinggi memiliki kecenderungan individualistis, secara perilaku mereka cenderung bersikap tidak mau kalah dengan temannya yang lain sehingga daya saing kelas cukup tinggi. Karakter kelas yang semacam ini tidak memungkinkan untuk guru menerapkan model pembelajaran kooperatif, karena peserta didik secara individual mampu untuk bekerja secara mandiri. Apabila dipaksakan menerapkan model pembelajaran kooperatif, kemungkinan kecil kegiatan belajar mandiri yang diharapkan akan berjalan dengan baik. Sebaliknya, di kelas yang kemampuan peserta didiknya heterogen, guru dapat menerapkan model pembelajaran yang bersifat kooperatif, sehingga semua siswa dapat belajar sesuai dengan kebutuhannya. Kelas yang bersifat heterogen memerlukan perlakuan khusus dari guru untuk menciptakan suasana belajar yang kondusif dan supportif. Model pembelajaran kooperatif dapat mendorong peserta didik untuk memiliki sikap kerja sama dengan mendorong mereka untuk saling memberikan penguatan antara peserta didik yang keterampilan kognitif tinggi kepada peserta didik yang berketerampilan kognitif rendah (Sharan \& Sharan, 1992; Slavin dkk., 1985).

\section{Perkembangan Teknologi}

Hari ini kita berada di zaman yang didengungkan sebagai Era Revolusi Industri 4.0, sebuah istilah sebagai penengarai perubahan zaman yang begitu signifikan dengan perkembangan teknologi yang beigtu pesat. Teknologi yang hadir saat ini memberikan dampak secara menyeluruh kepada sendi-sendi kehidupan. Segala sesuatu bersifat lebih mudah, praktis, dan cepat karena perkembangan teknologi. Kemudahan yang ada saat ini tentu saja dapat 
difungsikan untuk memeberikan kemudahan dalam kegiatan pembelajaran sejarah. Pemanfaatan media elektronik yang digunakan di dalam pembelajaran sejarah memberikan banyak kemungkinan kepada peserta didik untuk mengakses informasi yang jauh dari kehidupan mereka, karena itulah sifat dasar dari media adalah untuk mendekatkan yang jauh. Pemanfaatan media pembelajaran dalam pembelajaran sejarah sudah mulai banyak dilakukan selain untuk memberikan kemudahan kepada peserta didik dalam mencari informasi, juga untuk membuat pembelajaran sejarah menjadi lebih menarik. Dengan menggunakan media pembelajaran, materi sejarah dapat dihadirkan secara langsung kepada peserta didik melalui gambar, audio visual dan bentuk lainnya. Seperti misalnya penelitian yang dilakukan oleh Efendi dkk., (2018) dengan mengembangkan sebuah media pembelajaran berbasis animasi yang mampu menghadirkan wujud candi dalam bentuk 3D, atau yang lebih akrab disebut sebagai Augmented Reality. Media pembelajaran tersebut dapat memberikan gambaran yang konkrit kepada peserta didik bagaimana wujud candi dan relief-relief yang ada di dalamnya. Alat yang digunakan untuk mengakses media pembelajaran ini adalah smartphone yang dimiliki peserta didik, artinya mudah dan praktis untuk diakses.

Riset lainnya yang juga menunjukkan pemanfaatan media pembelajaran dilakukan oleh (Mahardika \& Putra, 2020) dengan memanfaatkan media pembelajaran komik digital. Komik yang secara umum dipahami sebagai bahan bacaan yang berisi cerita fiksi dapat dibentuk dan diubah menjadi media pembelajaran sejarah. Dalam konteks ini komik tidak lagi berisi tentang cerita fiksi, subtansi yang dimuat di dalam komik adalah cerita sejarah yang dapat dipertanggungjawabkan secara akademis. Tentu saja sejarah akan menjadi lebih menarik untuk peserta didik apabila disajikan dengan bentuk kekinian. Beberapa riset tersebut merupakan contoh sekaligus penggambaran objektif dari pemanfaatan teknologi dalam kegiatan pembelajaran sejarah. Riset tersebut merupakan hasil dari penelitian pengembangan yang memakan waktu dan proses cukup panjang, karena untuk dapat menggunakan media pembelajaran yang dikembangkan secara mandiri oleh peneliti harus melewati serangkaian uji lapangan (Gall dkk., 2003; Sugiyono, 2012). Maka dari itu, apabila guru tidak memiliki banyak waktu untuk melakukan penelitian pengembangan, satu hal yang dapat dilakukan untuk memanfaatkan teknologi di dalam kegiatan pembelajaran sejarah adalah mendayagunakan smartphone untuk mengakses informasi tambahan dari internet dalam melengkapi materi yang disajikan dalam sumber belajar peserta didik.

Dalam menyusun strategi pembelajaran yang berbasis pada pemanfaatan teknologi, guru tetap harus berhati-hati di dalam menyusun dan melaksanakannya. Keterbukaan informasi yang tersedia di ruang publik yang dapat diakses melalui smartphone, perlu untuk tetap diseleksi sebelum digunakan sebagi bahan referensi dalam belajar. Pasalnya, beberapa informasi yang tersedia di internet tidak kesemuanya memiliki kevalidan informasi, khususnya informasi seputar sejarah. Banyak tulisan tentang berbagai peristiwa sejarah yang dimuat di blogspot, wordpress, atau website non akademis lainnya. Persoalannya kemudian adalah, tidak semua peserta didik memiliki kesadaran untuk memilah dan memilih informasi yang tersedia. Apabila ditinjau dari 
perspektif sejarah secara keilmuan, salah satu syarat untuk mengkaji persitiwa masa lalu adalah verifikasi sumber untuk melakukan kroscek otentisitas dan kredibilitas sumber (Kuntowijoyo, 2005; Sjamsuddin, 2007). Sumber yang tersedia di internet tidak semuanya otentik dan kredibel untuk digunakan, sehingga pengawasan guru terhadap peserta didik dalam mengakses informasi sangat diperlukan. Hal ini dilakukan untuk meminimalisir miskonsepsi peserta didik, serta untuk memberikan pengetahuan kepada peserta didik bahwa di dalam mempelajari peristiwa masa lalu tidak boleh asal-asalan dalam menggunakan informasi yang akan dijadikan bahan kajian. Selain itu, dengan memilih dan memilah informasi yang sesuai akan dapat memberikan kekuatan akademis dari hasil kajian.

Salah satu cara yang bisa dilakukan guru untuk meminimalisir kesalahan peserta didik dalam mengakses dan menggunakan informasi sebagai bahan kajian adalah dengan mengarahkan peserta didik untuk mengakses jurnal ilmiah melalui google scholar atau mengakses website sejarah yang bereputasi seperti historia.id (Tim Redaksi Historia, t.t.). Jurnal ilmiah merupakan kumpulan artikel yang substansinya dapat dipertanggungjawabkan secara akademis sehingga artikel yang dimuat di dalam jurnal ilmiah dapat dijadikan sumber tambahan di dalam pembelajaran sejarah. Selain jurnal ilmiah, guru juga dapat mengarahkan peserta didik untuk mengakses website sejarah yang bereputasi. Reputasi website dalam hal ini adalah website yang secara khusus membahas peristiwa sejarah, dan wesbite ini dirancang oleh orang yang berkompeten di dalam bidang sejarah. Seperti misalnya website historia.id yang dirancang oleh salah seorang sejarawan terkemuka di Indonesia. Maka dalam hal ini, website dapat dijadikan sumber untuk menambah informasi apabila secara legitimasi moral dan akademis, website tersebut memang dirancang oleh orang yang ahli di bidang sejarah. Dengan demikian, dalam situasi ini peran guru menjadi sentral dalam memberikan arahan kepada peserta didik, sekaligus memberikan pengetahuan untuk memilah dan memilih informasi yang tepat, sehingga kemudian peserta didik memiliki pemahaman dan keterampilan di dalam menyeleksi informasi sebelum digunakan sebagai sumber belajar.

\section{Relevansi Materi Sejarah dengan Lingkungan Peserta Didik}

Materi yang dimuat di dalam buku teks siswa dalam kerangka pembelajaran sejarah umum masih identik dengan narasi sejarah-sejarah politik tentang kekuasaan dan jatuh bangun sebuah pemerintahan dalam periode tertentu (Mahardika, 2020). Inilah yang kemudian memunculkan image bahwa pembelajaran sejarah dianggap kurang menarik. Pasalnya, materi-materi yang dipelajari siswa notabene adalah sesuatu yang jauh dari lingkungan hidupnya sehingga pemaknaan siswa terhadap sejarah masih relatif kurang (Ammert dkk., 2020; Thorp \& Persson, 2020). Paradigma baru dalam pembelajaran sejarah hari ini tampaknya sudah mulai mengalami perubahan. Terbukti dari beberapa artikel hasil penelitian yang dimuat di dalam jurnal-jurnal ilmiah sudah tampak menyisipkan lokalitas atau materi-materi sejarah lokal di tengah materi sejarah secara umum (Lihat Abidin, 2020; Sayono dkk., 2019; Sulistyo, 2019; Utami, 2020). Hal ini tentu saja menjadi 'angin segar' bagi pembelajaran sejarah. Munculnya kesadaran akan lokalitas 
tampaknya merupakan sebuah dampak dari era globalisasi yang sekarang ini sedang kita alami bersama. Kesadaran akan lokalitas ini muncul ketika sendi-sendi kehidupan sudah dipengaruhi oleh produk-produk global sehingga beberapa orang menyadari perlunya kembali kepada lokalitas untuk kembali mengenali identitasnya sebagai sebuah bangsa (Amato, 2002; Garg, 2007; Lee \& Molebash, 2014).

Sejarah lokal hari ini sedang menjadi topik yang cukup hangat menjadi perbincangan dan perhatian para sejarawan dan pedagog sejarah. Kemenarikan ini bertumpu pada aspek lokalitas yang cukup problematis karena selalu mengalami perubahan cakupan dan maknanya. Istilah lokal seringkali dibenturkan dengan konsep interlokal (regional, nasional, global). Makna lokalpun tidak statis dan tunggal tetapi selalu berubah sesuai konteks zaman (Warto, 2017). Kondisi ini tidak harus disikapi secara berlebihan, tidak harus berpikir secara dikotomis dengan mempertentangkan antara yang lokal dengan yang nasional atau internasional. Secara garis besar, studi mengenai sejarah lokal di Indonesia memiliki empat corak, yakni: 1) studi yang difokuskan pada suatu peristiwa tertentu, 2) studi yang menekankan pada struktur, 3) studi yang mengambil perkembangan aspek tertentu dalam kurun waktu tertentu dan 4) Studi yang menjelaskan perkembangan daerah tertentu (Abdullah, 1985).

Penelitian dan penulisan sejarah lokal dalam konteks pembelajaran sejarah tentu memiliki aspek yang khas. Pertama, kajian sejarah lokal dapat menjadi sarana pembelajaran sejarah yang bersifat konstekstual. Penelitian sejarah lokal dapat dikembangkan dan diwujudkan menjadi bahan ajar yang berbasis pada aspek lokalitas lingkungan peserta didik. Mengingat buku-buku teks sejarah yang diterbitkan secara nasional sampai hari ini belum dapat mengakomodir sejarah lokal secara spesifik. Untuk mengisi kekurangan tersebut, keaktifan guru untuk meneliti atau menulis sejarah lokal yang kemudian hasilnya dapat disisipkan di tengah narasi besar sejarah nasional akan menjadi satu kontribusi penting. Hasil penelitian lokal tersebut kemudian dapat menjadi salah satu bahan pembahasan sejarah yang relevan bagi peserta didik untuk lebih mengenal lingkungan di sekitarnya. Peserta didik juga dapat dilatih untuk melakukan penelitian sejarah lokal. Dengan mengetahui dan mengalami proses penelitian, peserta didik dirangsang rasa keingintahuannya untuk mencari dan mengolah informasi. Kegiatan semacam itu juga melatih peserta didik untuk lebih kritis, dengan tidak menerima informasi yang ada begitu saja. Setiap informasi perlu diverifikasi, dengan harapan mereka tidak mudah tertipu oleh berita atau informasi yang keliru. Dari data yang telah berhasil dikumpulkan dan diverifikasi, peserta didik kemudian akan terlatih untuk merekonstruksi sebuah peristiwa. Kegiatan ini juga melatih penggunaan nalar secara logis dan berargumentasi dengan dukungan data empiris. Sebagai proses belajar, guru juga perlu mengingatkan peserta didik agar mereka juga tidak terlalu cepat mengambil kesimpulan, terutama yang terkait dengan dimensi prognosis (Hariyono, 2017).

Pembelajaran sejarah lokal dianggap sebagai pendekatan yang cocok untuk diterapkan dalam rangka memberikan pengajaran tentang lokalitas (Sulistyo dkk., 2019). Dengan menyisipkan materi seputar peristiwa lokal, dapat memberikan gambaran kepada siswa bahwa kejadian-kejadian sejarah juga terjadi di lingkungan sekitar mereka. Orientasi menyajikan sejarah 
lokal kepada siswa adalah untuk memposisikan mereka kepada "situasi kesejarahan" karena peristiwa yang disajikan adalah peristiwa yang berada di lingkungan sekitar mereka (Booth, 2003; Lévesque, 2008). Di samping itu, kehadiran sejarah lokal juga dapat menghadirkan diskursus baru di dalam kegiatan pembelajaran sehingga perspektif yang dibangun melalui sajian sejarah lokal dapat diinternalisasi ke dalam diri masing-masing peserta didik (Carretero, 2017). Seyogyanya, pembelajaran sejarah lokal perlu untuk selalu dikembangkan supaya peserta didik juga memiliki keterikatan emosional dengan materi yang sedang mereka pelajari sehingga proses belajar sejarah dapat menempatkan peserta didik sebagai subjek yang secara langsung terlibat dalam pengkajian peristiwa sejarah, terutama peristiwa yang memiliki nilai lokalitas (Drake \& Brown, 2003; Labbett, 1979). Pembelajaran sejarah lokal dapat dilakukan dengan tahapan-tahapan berikut:

1. Pengenalan konsep sejarah lokal

Sebelum masuk kepada materi yang hendak dipelajari, alangkah lebih baik guru memberikan pengertian kepada peserta didik terkait pengertian dan konsep sejarah lokal supaya mereka memiliki pra-pemahaman yang proporsional.

2. Menyajikan materi sejarah lokal sesuai dengan konteks materi sejarah secara umum Peristiwa sejarah lokal disipkan secara kontekstual dengan materi yang sedang dipelajari sesuai dengan Kompetensi Dasar yang ada. Dalam hal ini guru dituntut untuk memiliki pemahaman materi yang mumpuni sehingga sisipan peristiwa lokal yang akan diintegrasikan tepat sasaran.

3. Menginstruksikan siswa untuk menggali sumber melalui internet

Perkembangan teknologi perlu untuk dimanfaatkan di dalam pembelajaran sejarah, terutama untuk menggali sumber yang tersedia secara online (Kelly, 2013). Pendampingan guru diperlukan untuk menyeleksi keabsahan sumber-sumber yang digunakan.

\section{SIMPULAN}

Pembelajaran sejarah selalu mencari bentuk sempurnanya dari waktu ke waktu. Dalam proses menuju kesempurnaan itu, peran agen pembelajaran (utamanya guru, dan peserta didik) sangat diperlukan supaya pembelajaran sejarah menjadi lebih berkualitas dalam rangka memberikan pengetahuan tentang masa lalu, dan memaknainya sebagai sebuah sikap reflektif. Pembelajaran sejarah yang konservatif selalu menempatkan guru sebagai subjek dan pusat pembelajaran, sehingga peserta didik tidak memiliki banyak kesempatan untuk mengasah keterampilan belajarnya, yang kemudian hal itu justru akan mematikan potensi peserta didik itu sendiri. Maka, di dalam paradigma baru pembelajaran sejarah, ada upaya untuk melakukan transformasi pembelajaran yang sebelumnya bersifat satu arah (teaching oriented), menajdi pembelajaran yang berpusat kepada aktifitas belajar peserta didik secara mandiri (student centered). Ide besar ini tentunya harus dibarengi dengan praktik pembelajaran yang proporsional agar tujuan itu dapat tercapai dengan maksimal. Memberikan kesempatan yang luas kepada peserta didik untuk belajar secara mandiri merupakan upaya konkrit untuk membentuk pesrta didik yang memiliki karakter dan kecakapan 
dalam aspek akademis maupun keterampilan kognisi sosial. Mengingat di dalam kegiatan belajar mandiri, peserta didik dilatih untuk membangun pengetahuan secara konstruktiv, serta mendorong peserta didik untuk mengembangkan kognisi sosialnya dengan kegiatan diskusi. Proses pembangunan pengetahuan akan menjadi lebih sempurna apabila pengetahuan yang dimiliki seorang individu dapat dibagikan dengan bertukar pikiran terhadap teman sebayanya, karena dengan diskusi peserta didik akan mendapatkan perspektif yang lebih kompleks, serta belajar untuk menghargai pendapat teman belajarnnya. Sehingga dalam satu kegiatan pembelajaran yang berorientasi kepada student active learning dapat mencakup dua aspek yang telah disebutkan sebelumnya, yakni kecakapan akademis dan kognisi sosial.

\section{DAFTAR RUJUKAN}

Abdullah, T. (1985). Sejarah Lokal di Indonesia. Gadjah Mada University Press.

Abidin, N. F. (2020). Pembelajaran Sejarah Lokal di Sekolah Pedesaan dan Vokasi. Jurnal Pendidikan Sejarah Indonesia, 3(1), 88-99.

Ahmad, T. A. (2016). Sejarah Kontroversial Di Indonesia: Perspektif Pendidikan. Yayasan Pustaka Obor Indonesia.

Amato, J. A. (2002). Rethinking Home: A Case for Writing Local History. University of California Press. Ammert, N., Sharp, H., Löfström, J., \& Edling, S. (2020). Identifying Aspects of Temporal Orientation in Students' Moral Reflections. History Education Research Journal, 17(2), 132-150.

Barton, K. C., \& Levstik, L. S. (2004). Teaching History for the Common Good. Taylor \& Francis.

Booth, A. (2003). Teaching History at University: Enhancing Learning and Understanding. Routledge. Carretero, M. (2017). Palgrave Handbook of Research in Historical Culture and Education. Springer Berlin Heidelberg.

Dewey, J. (2004). Democracy and Education: An Inroduction to the Philosophy of Education. Global Media.

Dick, W., Carey, L., \& Carey, J. O. (2015). The Systematic Design of Instruction (Eighth edition). Pearson.

Drake, F. D., \& Brown, S. D. (2003). A Systematic Approach to Improve Students' Historical Thinking. The History Teacher, 36(4), 465-489.

Efendi, M. Y., Lutfi, I., Utami, I. W. P., \& Jati, S. S. P. (2018). Pengembangan Media Pembelajaran Sejarah Augmented Reality Card (Arc) Candi-Candi Masa Singhasari Berbasis Unity3D pada Pokok Materi Peninggalan Kerajaan Singhasari untuk Peserta Didik Kelas X KPR1 SMK Negeri 11 Malang. Jurnal Pendidikan Sejarah Indonesia, 1(2), 176-187.

Epstein, T. (2009). Interpreting National History: Race, Identity, and Pedagogy in Classrooms and Communities. Routledge.

Gall, M. D., Gall, J. P., \& Borg, W. R. (2003). Educational Research: An Introduction. Pearson Education, Inc.

Garg, B. (2007). Teaching of History. Rajat Publications.

Giroux, H. A. (2011). On Critical Pedagogy. Continuum. 
Gunarsa, dkk. (2008). Psikologi Perkembangan Anak dan Remaja. PT BPK Gunung Mulia.

Hariyono. (2017). Sejarah Lokal: Mengenal yang Dekat, Memperluas Wawasan. Jurnal Sejarah dan Budaya, 11(2), 160-166.

Hariyono. (2018). Pendidikan Sejarah dan Karakter Bangsa Sebuah Pengantar Dialog. Jurnal Pendidikan Sejarah Indonesia, 1(1), 1-22.

Husbands, C., Kitson, A., \& Pendry, A. (2003). Understanding History Teaching. Open University Press.

Kelly, T. M. (2013). Teaching History in The Digital Age. The University of Michigan Press.

Kementerian Pendidikan dan Kebudayaan. (2017). MODEL SILABUS MATA PELAJARAN SEKOLAH MENENGAH ATAS/SEKOLAH MENENGAH KEJURUAN/MADRASAH ALIYAH/MADRASAH ALIYAH KEJURUAN (SMA/MA): MATA PELAJARAN SEJARAH INDONESIA. Kementerian Pendidikan dan Kebudayaan Republik Indonesia.

Kreisberg, S. (1992). Transforming Power: Domination, Empowerment, and Education. SUNY Press. Kuntowijoyo. (2005). Pengantar Ilmu Sejarah. Bentang Pustaka.

Labbett, B. D. C. (1979). Local History in the Classroom. The Social Studies, 70(2), 62-66.

Lee, J. K., \& Molebash, P. E. (2014). Becoming Digital: Using Personal Digital Histories to Engage Teachers in Contemporary Understandings of Teaching Social Studies. The Journal of Social Studies Research, 38(3), 159-172.

Lévesque, S. (2008). Thinking Historically: Educating Students for The Twenty-First Century. Buffalo: University of Toronto Press.

Mahardika, M. D. G. (2020). Kepentingan Rezim dalam Buku Teks Sejarah di Sekolah. ISTORIA: Jurnal Pendidikan dan Sejarah, 16(2), 1-7.

Mahardika, Moch. D. G., \& Putra, N. W. (2020). The Utilization Interactive Digital Media Comic In Indonesian Historical Learning to Support Independent Learning at SMA Al-Izzah. Seminar Nasional Pembelajaran Sejarah (SPNS UNS 2020), 184-192.

Metzger, S. A., \& Harris, L. M. (Ed.). (2018). The Wiley International Handbook of History Teaching and Learning (First edition). Wiley-Blackwell.

Priansa, D. J. (2019). Pengembangan Strategi \& Model Pembelajaran. Pustaka Setia.

Rusman. (2012). Model-Model Pembelajaran. PT Raja Grafindo Persada.

Sayono, J., Ayundasari, L., Sulistyo, W. D., \& Ridhoi, R. (2019). Utilization of Syphon Metro Kepanjen as Outdoor Learning Site for History Students. 69-73.

Seixas, P. C. (Ed.). (2004). Theorizing Historical Consciousness. University of Toronto Press.

Sharan, Y., \& Sharan, S. (1992). Expanding Cooperative Learning Through Group Investigation. Teachers College Press.

Sjamsuddin, H. (2007). Metodologi Sejarah. Ombak.

Slavin, R., Sharan, S., Kagan, S., Hertz-Lazarowitz, R., Webb, C., \& Schmuck, R. (Ed.). (1985). Learning to Cooperate, Cooperating to Learn. Springer US.

Sugiyono. (2012). Metode Penelitian Pendidikan: Pendekatan Kuantitatif, Kualitatif dan R\&D. Alfabeta. 
Sulistyo, W. D. (2019). Study on Historical Sites: Pemanfaatan Situs Sejarah Masa Kolonial di Kota Batu Sebagai Sumber Pembelajaran Berbasis Outdoor Learning. Indonesian Journal of Social Science Education (IJSSE), 1(2), 124-135.

Sulistyo, W. D., Nafi'ah, U., \& Idris, I. (2019). The Development of E-PAS Based on Massive Open Online Courses (MOOC) on Local History Materials. International Journal of Emerging Technologies in Learning (IJET), 14(09), 119. https://doi.org/10.3991/ijet.v14i09.10143

Thorp, R., \& Persson, A. (2020). On Historical Thinking and The History Educational Challenge. Educational Philosophy and Theory, 52(8), 891-901.

Tim Redaksi Historia. (t.t.). Historia: Masa Lampau Selalu Aktual [Web Site]. Historia.id. https://historia.id/

Utami, I. W. P. (2020). Pemanfaatan Digital History Untuk Pembelajaran Sejarah Lokal. Jurnal Pendidikan Sejarah Indonesia, 3(1), 52-62.

Villacañas de Castro, L. S. (2016). Critical Pedagogy and Marx, Vygotsky and Freire: Phenomenal Forms and Educational Action Research. Palgrave Macmillan.

Warto. (2017). Tantangan Penulisan Sejarah Lokal. Jurnal Sejarah dan Budaya, 11(1), 153-159.

Zed, M. (2004). Metode Penelitian Kepustakaan. Yayasan Obor Indonesia. 